\title{
Pulmonary changes during acute experimental murine manson schistosomiasis
}

\author{
Alterações pulmonares na esquistossomose aguda \\ experimental em camundongos
}

\author{
Samaly dos Santos Souza', Joaquim Pereira de Souza Neto ${ }^{1}$ \\ and Zilton A. Andrade ${ }^{1}$
}

\begin{abstract}
Dry cough, dyspnea and manifestations of bronchial asthma have recently been observed in patients with acute schistosomiasis. To investigate the type and pathogenesis of these conditions, an experimental mouse model for acute schistosomiasis was used. Forty mice were divided into four groups of ten each: three infected groups and a non-infected control group. The animals were examined 7, 28-35 and 40 days after exposure to cercariae. During the acute phase of the infection (28-35 days), a process of multifocal interstitial pneumonitis involving the peribronchial, peribronchiolar and subpleural tissues was found. This process was not seen during the other phases of the infection. Indirect immunofluorescence failed to demonstrate the presence of schistosomal antigens in the acute-phase lesions. The pneumonitis was attributed to products (inflammatory mediators) from acutephase periovular necrotic-inflammatory lesions in the liver that were transported to the lungs by the bloodstream.
\end{abstract}

Key-words: Acute schistosomiasis. Pneumonitis. Dyspnea. Periovular granuloma.

\section{RESUMO}

Recentemente tem sido observada a presença de tosse seca, dispnéia, e manifestações de asma brônquica em pacientes com esquistossomose aguda. Para se investigar sobre o tipo e patogenia de tais lesões foi utilizado um modelo experimental de esquistossomose aguda no camundongo. Quarenta animais foram divididos em quatro grupos de 10 animais cada, 3 infectados e um grupo controle não-infectados. Os exames foram feitos após 7, 2835, e 40 dias após a exposição cercariana. Na fase aguda da infecção (28-35 dias), encontrou-se um processo de pneumonite intersticial multifocal, envolvendo os tecidos peribrônquicos, peribronquiolares e subpleural, processo que esteve ausente nas outras fases examinadas. Não foi possível a demonstração de antígenos do Schistosoma. mansoni nas lesões da fase aguda, através da técnica de imuno-fluorescência indireta. A pneumonite foi atribuída a produtos (mediadores inflamatórios) gerados nas lesões hepáticas necro-inflamatórias periovulares da fase aguda, e transportados para os pulmões pela circulação sanguínea.

Palavras-chaves: Esquistossomose aguda. Pneumonite. Dispnéia. Granuloma peri-ovular.

The last twenty years have witnessed a change in the clinicalpathological presentation of human schistosomiasis. This has probably resulted from the introduction of effective and simple new curative drugs, coupled with progressive socioenvironmental improvements $^{3}$. One impressive new development has been a drastic reduction in the incidence and prevalence of the most advanced forms of the disease, such as the hepatosplenic form, and its complications ${ }^{1}$. Another curious change has been the trend towards upsurges of new foci of transmission, sometimes revealed by outbreaks of cases of acute schistosomiasis ${ }^{5}$. Clinical studies on these new cases of acute schistosomiasis have been revealing intriguing manifestations related to the immunopathology of

1. Laboratory of Experimental Pathology, Gonçalo Moniz Research Center, Salvador, BA, Brazil.

Address to: Dr. Zilton A. Andrade. LAPEX/CPqGM. Waldemar Falcão st., 121- Candeal, 40296-710 Salvador, BA, Brazil.

Tel: $55713176-2206$

e-mail: zilton@bahia.fiocruz.br

Recebido para publicação em 16/09/2009

Aceito em 03/02/2009 the disease. One of these studies was on the type of pulmonary involvement during the course of acute schistosomiasis ${ }^{7}$.

Acute schistosomiasis is related to the migration of parasite larvae through the lungs and a rise in the host immune response towards parasite larvae, worms and eggs. While early infection usually passes unnoticed among residents of endemic areas, it causes a variety of manifestations among people from nonendemic regions. Fever and prostration are the main clinical manifestations, soon followed by persistent dry cough, asthmatic manifestations, abdominal pain, diarrhea and myalgia ${ }^{6}$. Leukocytes are observed in about 25 to $30 \%$ of the patients, while eosinophilia is present in almost all cases with acute manifestations. The eosinophil rate usually reaches $50 \%$ or more?

These respiratory manifestations have been attributed to an allergic reaction caused by the passage of parasite larvae, but recent functional studies have revealed that the pulmonary involvement is predominantly interstitial, and more related to the levels of immune complexes than to IgE serum levels ${ }^{7}$. Dry cough and episodes of bronchial asthma are frequently registered, accompanied by high production of inflammatory cytokines, such as IL-1, IL-6 and TNF $\alpha^{8}$. 
The present investigation explored the pathogenesis of the pulmonary changes that occur during the early phases of experimental Schistosoma mansoni infection, by taking advantage of the existence of a good mouse model for acute schistosomiasis ${ }^{2}$.

\section{MATERIALS AND METHODS}

Animals. Forty healthy Swiss Webster mice of both sexes, weighing around 15-20g were divided into four experimental groups of ten animals each. They were kept in large metallic boxes (five animals per box), in a well ventilated room at a temperature of $25-27^{\circ} \mathrm{C}$, with free access to water and to a balanced commercial diet for mice.

Infection. Thirty mice were individually subjected to infection with 50 recently eliminated Schistosoma mansoni cercariae of the Feira de Santana strain (Andrade \& Sadigursky, 1985), and ten remained as non-infected intact controls.

Experimental groups. Group 1. Animals that were killed seven days after exposure to cercariae. This is the time of greatest migration of cercariae the lungs.

Group 2. Animals that were killed between the $28^{\text {th }}$ and $44^{\text {th }}$ days after infection with cercariae. This covered the period during which mature schistosomal eggs start to be present, and is experimentally representative of acute murine schistosomiasis according to Andrade \& Azevedo ${ }^{2}$.

Group 3. Animals killed between 12 and 15 weeks after infection. This is representative of chronic schistosomiasis.

Group 4. Non-infected, normal controls among which four animals were killed and examined together with Group 2, and the others were killed over the study period to serve as controls for the other groups.

Procedures. Under anesthesia and aseptic conditions, the animals were killed by exsanguination after severing the abdominal aorta. Fragments from the liver and spleen were placed in neutral $10 \%$ formalin. The lungs were fixed by injecting the fixative directly into the trachea using a syringe, while taking care to avoid intraalveolar overdistension. All the material remained in the fixative for at least 24 hours before dehydration and paraffin embedding. Paraffin sections were stained with routine hematoxylin and eosin, and with Sirius red for collagen.

Paraffin sections from the lungs and liver were subjected to the procedure for immunofluorescence microscopy to investigate Schistosoma mansoni antigens. After deparaffinization, hydration and washing in neutral phosphate-buffered saline (PBS), the sections were covered with a pool of human sera from Schistosoma mansoni-infected patients, either at full concentration or at dilutions of 1:2 and 1:10, followed by treatment with 1:60 fluoresceinated anti-human globulin (Dako, USA). The sections were examined using a Zeiss microscope with barrier and exciter filters, under UV light.

\section{RESULTS}

All the animals exposed became infected, and this was easily perceived in Groups 2 and 3 by the presence of numerous parasite eggs in the sections examined. The evidence of infection was indirect for Group 1. The control animals presented microscopic structures in the lungs, liver and spleen that were within normal limits.

On the seventh day after infection, the histological findings in the lungs were essentially normal. An exhaustive search for schistosomal larvae and significant inflammatory foci was conducted, but none were found.

The liver sections from Group 2 animals revealed the presence of several mature schistosomal eggs in the center of large, scattered periovular granulomas, usually within a necrotic center of ischemic or purulent nature. In the latter, eosinophils were abundant. Furthermore, there were many inflammatory cells infiltrating the portal spaces and also in between the liver cell plates.

The spleen exhibited diffuse hyperplasia of the cells in both the red and white pulps, together with intense active congestion of the splenic sinuses.

The changes in the lungs were restricted to the interstitial tissues, especially those around large and medium size bronchi, and also in the subpleural region. These changes consisted of focal or sometimes diffuse, mild to moderate mononuclear infiltration (Figure 1), associated with variable degrees of edema. The cells in the infiltration were mainly lymphocytes and a few macrophages, but eosinophils were rather absent. The alveoli spaces were empty, and no significant change was seen in the alveolar walls, except a varying degree of congestion. No parasitic structures were ever seen in the sections examined. In Group 3, the classical lesions of chronic schistosomiasis were present, with many periovular granulomas scattered throughout the liver and lungs, while in the spleen, changes representing chronic congestion predominated.

Immunofluorescence failed to reveal any presence of schistosomal antigen within the peribronchial foci of cell infiltrations observed in the animals from Group 2, either as free forms or within cells. However, when schistosomal eggs were present in the section, bright apple-green fluorescence marked their contents and sometimes the periphery around them.

\section{DISCUSSION}

Manifestations of bronchial asthma with persistent dry cough have been registered among patients with acute schistosomiasis ${ }^{8}$. The pulmonary changes experimentally observed in the present study, during the course of acute infection in mice, were rather mild but consistent and well defined. They were representative of multifocal interstitial pneumonitis. Their location, which was predominantly peribronchiolar and peribronchial, but also subpleural to a lesser degree, may be correlated with a varying 

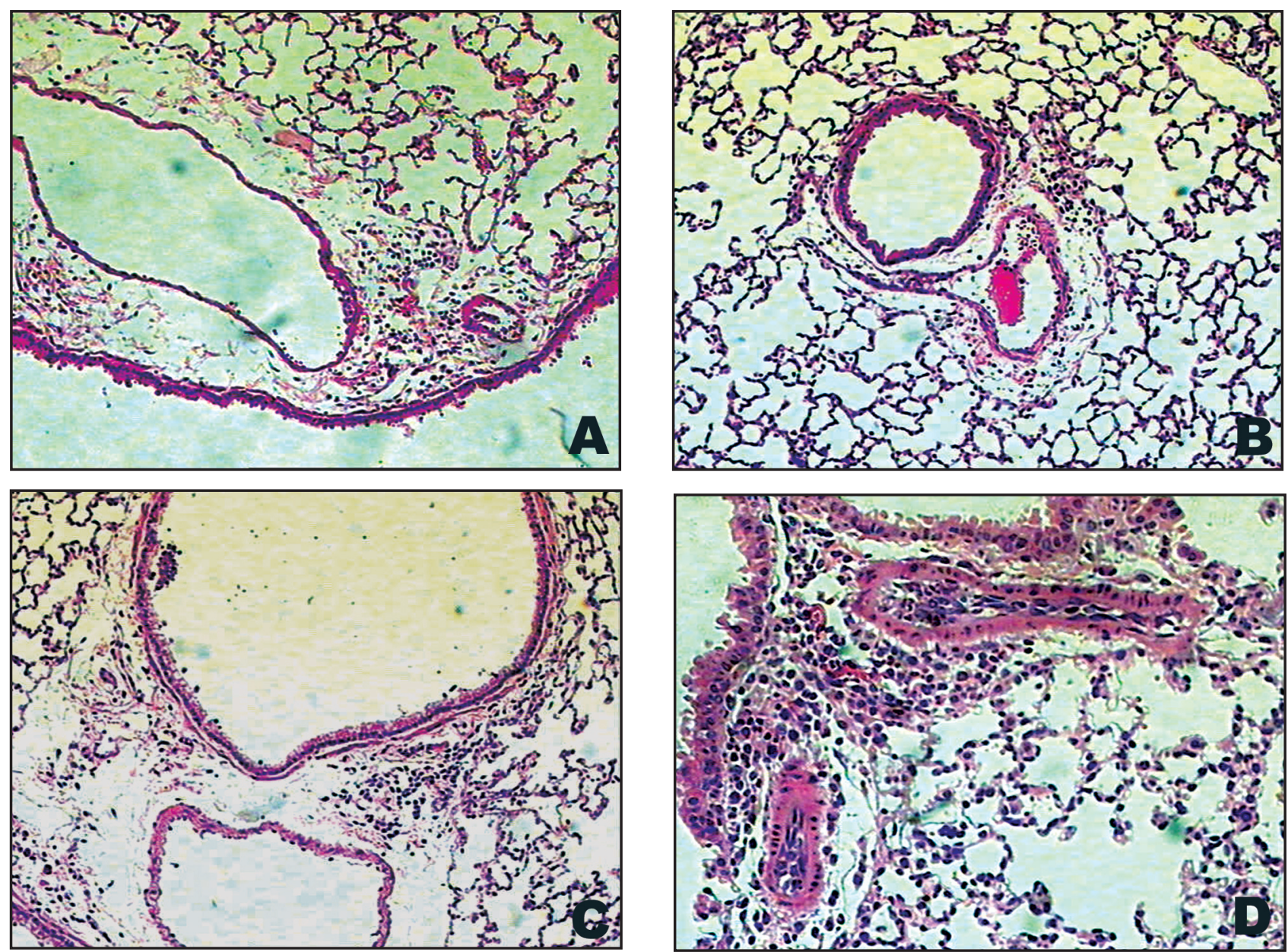

FIGURE 1 A, B, C AND D

Peribronchiolar spaces showing moderate edema and diffuse and focal infiltration of mononuclear leukocytes, with predominant lymphocytes, seen during the acute phase of Schistosoma mansoni infection in mice. H \& E; 100X (A, B and D); 200X (C).

degree of chronic irritation to the nervous structures in these locations from which the cough reflex may originate. This mild interstitial inflammation can probably be propagated toward the peritracheal tissues, where cough reflexes are more sensitive. From these findings, it is inevitable to speculate that this may indeed be the morphological substratum of the pulmonary manifestations seen in human cases of acute schistosomiasis. The logical explanation for inflammation in the lungs in the absence of parasite products, albeit observed only during the acute phase of schistosomiasis in mice, would be to suggest the presence of an immunological mechanism. The present study, which went in this direction, produced negative results but this does not definitively discard such a mechanism. It is likely that a series of complex mediators generated during the severe necrotic-inflammatory reactions in the liver reach the lungs via the bloodstream and cause irritation of sensitive peribronchial nervous structures.

Studies conducted during the course of acute human schistosomiasis have indicated that the inflammatory response is related to an immune reaction that is characterized by a marked increase in the levels of pro-inflammatory cytokines such as IL-1, IL-6 and TNF- $\alpha$.

Although the pulmonary manifestations of acute schistosomiasis in humans have been considered to be allergic reactions caused by the migration of schistosomula through the lungs ${ }^{7}$, the findings from the present experimental study did not produce data to support this. In fact, a study with day-by-day histological analysis of schistosomiasis among mice revealed that, following their first exposure to cercariae, no inflammatory reactions occurred anywhere until the first mature eggs appeared ${ }^{2}$.

\section{REFERENCES}

1. Andrade ZA. The situation of hepatosplenic schistosomiasis in Brazil today. Memórias de Instituto Oswaldo Cruz 93:58-75, 1998.

2. Andrade ZA, Azevedo TM. A contribution to the study of experimental acute schistosomiasis. An experimental trial. Memórias do Instituto Oswaldo Cruz 2:311-317, 1987 .

3. Andrade ZA, Bina AJC. The changing pattern of pathology due to Schistosoma mansoni infection. Memórias de Instituto Oswaldo Cruz 80:363-366, 1985.

4. Andrade ZA, Sadigursky M. Um estudo comparativo das cepas de Feira de Santana (Bahia) e Porto Rico do Schistosoma mansoni na infecção experimental do camundongo. Memórias do Instituto Oswaldo Cruz 80:37-40, 1985.

5. Carvalho EM, Andrade ZA. Imunopatologia da esquistossomose. In Coura JR (ed) Dinâmica das doenças infecciosas e parasitárias. Guanabara Koogan, Rio de Janeiro, p. 947-957, 2005.

6. Jesus AR, Silva A, Santana LB, Magalhães A, Almeida RP, Rego MA, Burattini MN, Pearce EG, Carvalho EM. Clinical and immunologic evaluation of 31 patients 
with acute Schistosomiasis mansoni. The Journal of Infectious Diseases 173:269-272, 2002

7. Lambertucci JR. Acute schistosomiasis: clinical, diagnostic and therapeutic features. Revista do Instituto de Medicina Tropical de São Paulo 35:399-404, 1993
8. Silva A. Avaliação de um surto de esquistossomose mansônica com seus aspectos clínicos, epidemiológicos e imunológicos. Tese de Doutorado, Universidade Federal de São Paulo, Escola Paulista de Medicina, São Paulo, SP, 2001.

9. Silva LM, Menezes RMC, Oliveira AS, Andrade ZA. Chemotherapeutic effects on larval stages of Schistosoma mansoni during infection and re-infection of mice. Revista da Sociedade Brasileira de Medicina Tropical 36:335-341, 2003. 